\title{
Farklı Gelişme Dönemlerinde Hasat Edilmiş Tritikale Hasılında Morfolojik Unsurların Besin Değeri
}

\author{
Gürhan Keleş \\ Adnan Menderes Üniversitesi, Ziraat Fakültesi, Zootekni Bölümü, Yemler ve Hayvan Besleme Anabilim Dalı, 09100 Aydın \\ e-posta: gurhankeles@msn.com; Tel.: +90 (256) 772 7024-2018; Faks: +90 (256) 7727233
}

\begin{abstract}
Özet
$\mathrm{Bu}$ çalışmada tritikale hasılının sapa kalkma, gebeleşme, başaklanma, süt olum ve hamur dönemlerinde belirlenen morfolojik unsurlarının besin değerleri araştırılmıştır. Yaprakların saplardan ortalama ham protein, ham yağ ve ham kül içerikleri sırasıyla, \%60, 21 ve 63 daha yüksek $(\mathrm{P}<0.05)$; buna karşın NDF, ADF ve selüloz içerikleri sırasıyla, \%16, 23 ve 27 daha düşük $(\mathrm{P}<0.05)$ olarak belirlenmiştir. Yaprakların ve sapların sapa kalkma ve hamur olum dönemlerinde içerdikleri HP değerleri sırasıyla, 265168 ve 186-41 g/kg kuru madde (KM) olarak belirlenmiş, bitki gelişimine bağlı olarak ham protein içeriğindeki düşüş saplarda daha belirgin $(\mathrm{P}<0.05)$ tespit edilmiştir. Yaprakların NDF içerikleri gebeleşme ve hamur olum dönemleri arasında benzer $(\mathrm{P}>0.05)$ belirlenirken, sapların NDF içerikleri süt olum dönemine kadar artmıştır $(\mathrm{P}<0.05)$. Yaprak ve sapların sapa kalkma ve hamur olum dönemlerinde NDF sindirilebilirlikleri sırasıyla, 852-779 ve 663-382 g/kg KM olarak belirlenmiş, sapların gelişme dönemine paralel olarak sindirilebilirlik değerlerindeki düşüş daha belirgin $(\mathrm{P}<0.05)$ belirlenmiştir. Araştırma sonucunda olgunlaşma ile sapların besin değerindeki düşüşün yaprak ve başaklara kıyasla çok daha belirgin olmasından dolayı, kaba yem üretimi amacıyla kullanılacak çeşitlerde sap oranı düşük çeşitlerin kullanılmasının ve yaprak-sap oranının buğdaygil otlarının hasat zamanın belirlenmesinde bir kriter olarak kullanılabileceği sonucuna varılmıştır.
\end{abstract}

Anahtar kelimeler: Besin değeri, gelişme dönemi, sap, sindirilebilirlik, tritikale hasıl1, yaprak

\section{Nutritive Value of Morphological Components in Triticale Forage Harvested at Different Maturity Stages}

\begin{abstract}
In this study, nutritive value of morphological fractions of triticale forage was measured at stem elongation, booting, ear emergence, milk and dough stages of maturity. Averaged across the maturity crude protein, crude fat and ash content of leaves were higher $(\mathrm{P}<0.05)$ than stem by 60, 21 and 63\% whereas NDF, ADF and cellulose content of leaf were lower $(\mathrm{P}<0.05)$ than stem by 16, 23 and $27 \%$, respectively. Crude protein content of leaves and stems at stem elongation and dough stages of maturity were $265-168$ and $186-41 \mathrm{~g} / \mathrm{kg}$ dry matter (DM), and the reduction in crude protein with maturity was more pronounced $(\mathrm{P}<0.05)$ in stem than leaves. The NDF content of leaves between booting and dough stages were similar $(\mathrm{P}>0.05)$, while it was increased $(\mathrm{P}<0.05)$ in stem at milk stage. NDF digestibility of leaves and stems at stem elongation and dough stages were $852-$ 779 and 663-382 g/kg DM and the increase in NDF content with maturity was more pronounced $(\mathrm{P}<0.05)$ in stem than leaves. It was concluded that due to fast decrease in nutritive value in stem compared to leaf or ear, it is vise to choose cultivar with low stem ratio and it should take into leaf-stem ratio at harvest.
\end{abstract}

Key words: Nutritive value, stage of maturity, digestibility, stem, triticale forage, leaf

\section{Giriş}

Ülkemizde kaliteli kaba yem kaynağı olarak yaygın bir şekilde mısır ve yonca bitkileri kullanılmaktadır. Ancak her iki bitkininde üretilmesi için yüksek miktarda suya ve belirli bir sıcaklığa ihtiyaç duyulmaktadır. Ayrıca bu bitkiler yetiştirildiği tarım alanlarında endüstri bitkileri ile de üretim alanı açısından rekabete girmektedirler. Buna karşın kurak koşullarda tek yıllık tahıl hasıllarının ürettikleri kuru madde $(\mathrm{KM})$ verimi $(\mathrm{kg} / \mathrm{da})$ oldukça dikkat çekici miktarlara ulaşabilmektedir. Albayrak ve ark. (2006) çalışmalarında kullandıkları 62 farklı tritikale hattından süt olum döneminde yapılan bir hasat sonucunda $838-1893 \mathrm{~kg} / \mathrm{da} \mathrm{KM}$ verimi elde ettiklerini bildirmişlerdir. Süt olum döneminde elde edilen bu yüksek değerler tahıl hasıllarının kaba yem üretme potansiyellerini ortaya koymaktadır. Ayrica, dane olgunluğunu beklemeden kaba yem üretimi amaciyla yapılacak erken hasadın hemen ardından sulama imkanı bulunan ülkemizin birçok bölgesinde silajlık misır üretimi de dahil olmak üzere ikinci bir ürün yetiştirmek mümkün olmaktadır.

Tahıl hasıllarının otlatılarak, kurutularak ya da 
silolanarak verim düzeyi farklı ruminantların beslenmesinde tek ya da diğer kaba yemlerle karışım yapılarak kullanılmaları mümkündür. Tahıl hasıllarının besin değerini etkileyen en önemli etken hasat zamanıdır. Çünkü tahıl hasıllarının ham protein (HP) ve sindirilebilirlik değerlerinde daha belirgin olmak üzere besin değeri bitki olgunluğundan oldukça etkilenmektedir (Helsel ve Thomas, 1987; Khorasani ve ark., 1997). Nitekim erken vejetatif dönemde farklı yulaf çeşitleri, buğday ve tritikale hasıllarında in-vitro KM sindirilebilirliğinin $891-912 \mathrm{~g} / \mathrm{kg}$, HP içeriğinin ise 137-349 g/kg KM arasında değiştiği bildirilirken (Coblentz ve Walgenbach, 2010), hamur olum döneminde hasat edilen farklı hasıl türlerinin in-vitro organik madde sindirilebilirlikleri $513 \mathrm{~g} / \mathrm{kg}$ KM'ye (Nadeau, 2007), HP içeriği ise $67 \mathrm{~g} / \mathrm{kg} \mathrm{KM}$ 'ye (Rustas ve ark., 2011) kadar düşebilmektedir. Tahıl hasıllarının hasat esnasındaki gelişme dönemi sadece besin değerini değil aynı zamanda besleme değerini de önemli derecede etkilemektedir. Özellikle başaklanma ile süt olum dönemi arasında hasat edilen tahıl hasıllarının besleme değerinin hamur olum döneminde hasat edilen hasıllardan düşük olduğu bildirilmektedir (Rustas ve ark., 2011).

Tahıl türlerinin besin ve besleme değeri hasıl türüne göre de değişiklik göstermektedir. Emile ve ark. (1997) süt olum dönemi sonunda hasat edilerek silolanmış 6 tritikale çeşidi, 2 buğday çeşidi, arpa ve çavdar içerisinde buğday silajlarının organik madde sindirilebilirliklerinin (\%61.6) arpa (\%57.6) ve çavdardan (\%54.7) daha yüksek olduğunu ve 6 tritikale varyetesinin ortalama organik madde sindirilebilirliklerinin (\%60.6) buğdaya yakın olduğu bildirirlerken; McCartney ve Vaage (1994) süt olum dönemlerinde biçilmiş arpa hasılının, KM ve HP sindirilebilirliğinin yulaf ve tritikaleden daha yüksek olduğunu bildirmişlerdir. Helsel ve Thomas (1987) ise başaklanma, süt ve hamur olum dönemlerinde hasat edilmiş çavdar, yulaf, buğday ve arpa içerisinde en yüksek sindirilebilir KM veriminin çavdardan elde edildiğini bununla beraber, başaklanmadan sonra diğer türlerin besin madde içeriğinin çavdardan daha yüksek olduğunu bildirmişlerdir.

Tahıl türlerinin besin ve besleme değeri hasıl türlerine ve gelişme dönemlerine göre farklılıklar gösterebilirse de tahıl türlerinin morfolojik unsurlarının besin değeri arasındaki farklılıklar, bitkinin tamamına kıyasla daha düşük olmaktadır (Cherney ve Marten, 1982). Bu nedenle tahıl hasıllarının morfolojik unsurlarının besin değerinin belirlenmesi ve bu morfolojik unsurların toplam KM üretimindeki miktarlarının belirlenmesi tahıl türlerinin farklı gelişme dönemlerinde besin değerlerinde oluşan farklılıkların daha iyi ortaya konulmasına ve optimum biçim zamanın belirlenmesine yardımcı olması beklenebilir.

Tritikale hasılları kardeşlenme döneminden başlayarak sapa kalkma, gebeleşme, başaklanma, süt olum veya hamur dönemlerinde gerek direk otlatılarak gerekse kuru ot ya da silolanarak ruminantların beslenmesinde değerlendirilebilmektedir. $\mathrm{Bu}$ çalışmada tritikale hasılının beş farklı gelişme dönemindeki morfolojik unsurlarının besin değerinin belirlenmesi amaçlanmıştır.

\section{Materyal ve Metot}

Araştırmanın materyalini tesadüf blokları deneme desenine göre 3 tekerrürlü olarak ekimi yapılmış tritikale hasılı (X Triticosecale wittmack) oluşturmuştur. Tritikale parsellerin her biri sapa kalkma, gebeleşme, başaklanma, süt olum ve hamur olum dönemlerinde örneklenmiştir. Parsellerin her birinden rasgele örneklenen en az beş adet bitki laboratuvar koşullarında morfolojik kısımlarına (yaprak, sap, başak ve ölü doku) ayrılarak kurutulmuştur. Yaprak kılıfı sap kısmına dahil edilmiştir. Kurutulmuş morfolojik unsurlar $1 \mathrm{~mm}$ 'lik elekten geçecek şekilde ögütülerek besin maddesi analizlerinde kullanılmıştır.

Örneklerin KM düzeyleri $60{ }^{\circ} \mathrm{C}$ 'de en az 48 saat süre ile ağırlık sabitleninceye kadar fanlı etüvde kurutma ile belirlenmiştir. Havada kuru örneklerin besin madde içeriklerinin $\mathrm{KM}$ esasına göre verilebilmesi için gerekli KM'ler ise $105{ }^{\circ} \mathrm{C}$ 'de 4 saat kurutma ile belirlenmiştir. Örneklerin HP, ham yă (HY) ve ham kül (HK) içerikleri AOAC (2003)'e; nötral çözücülerde çözünmeyen karbonhidrat (NDF) ve asit çözücülerde çözünmeyen karbonhidrat (ADF) içerikleri Van Soest ve ark. (1991)'e göre belirlenmiştir. NDF analizleri 1sıya dayanıklı $\alpha$-amilaz ve sodyum sülfit dahil edilerek yapılmıştır. Örneklerin asit çözücülerde çözünmeyen lignin (ADL) içerikleri ADF'si belirlenmiş örneklerin \%72'lik $\mathrm{H}_{2} \mathrm{SO}_{4}$ çözeltisinde 3 saat bekletme sonucunda tespit edilmiştir. Ín-vitro gerçek $\mathrm{KM}$ ve $\mathrm{NDF}$ sindirilebilirlikleri (NDFS) Ankom Daisy ${ }^{\mathrm{II}}$ inkubatör kullanılarak belirlenmiştir. In-vitro gerçek KM sindirilebilirlik tespitinde kullanılan rumen sıvıs1, 60:40 oranında kaba:karma yem ile yaşama payı gereksinimin 1.25 katı düzeyinde beslenen rumen kanüllü bir düveden alınmıştır.

Hemiselüloz (HS), NDF'den ADF; selüloz (SEL) ise ADF'den ADL çıkarılarak hesaplanmıştır. 
Araştırma sonuçları tesadüf blokları deneme planına uygun olarak SPSS 10 (2010) paket programında varyans analizine tabi tutulmuştur. Önemlilik kontrolleri 0.05 seviyesinde irdelenmiştir. Ortalamalar arasındaki farkların tespiti AÖF çoklu karşılaştırma testi ile yapılmıştır.

\section{Bulgular}

Tritikale hasılının sap ve yapraklarının sapa kalkma, gebeleşme, başak, süt olum ve hamur olum dönemlerinde tespit edilen besin değerleri Çizelge 1'de verilmiştir. Yaprakların HP içerikleri 186-265 g/kg KM, sapların ise 186-41 g/kg KM arasında değişmiş, yaprakların saplardan HP içeriğinin ortalama \%60 daha fazla $(\mathrm{P}<0.05)$ olduğu tespit edilmiştir. Yaprak ve sapların HP içeriği, bitki olgunlaşmasına paralel bir şekilde düşmüştür $(\mathrm{P}<0.05)$. HP içeriğindeki bu düşüşün saplarda çok daha belirgin $(\mathrm{P}<0.05)$ olduğu belirlenmiştir. Nitekim sapa kalkma ve hamur olum dönemleri arasında yaprakların HP içeriğindeki düşüş ortalama \%30 olurken, saplardaki düşüş \%78'e ulaşmıştır. Her dönemde HP içeriği yapraklarda, saplardan daha fazla tespit edilmiştir.

Çizelge 1. Farklı gelişme dönemlerinde sap ve yaprakların besin değeri $(\mathrm{g} / \mathrm{kg} \mathrm{KM})^{1}$

\begin{tabular}{|c|c|c|c|c|c|c|c|c|c|c|c|}
\hline Gelişme Dönemi & & $\mathrm{HP}$ & $\mathrm{HK}$ & HY & $\mathrm{NDF}$ & $\mathrm{ADF}$ & $\mathrm{ADL}$ & $\mathrm{HS}$ & SEL & KMS & NDFS \\
\hline Sapa kalkma & & $226 a$ & $116 \mathrm{a}$ & 52 & $470 \mathrm{~b}$ & $256 b$ & $48 \mathrm{c}$ & 215 & $208 b$ & $907 \mathrm{a}$ & $816 a$ \\
\hline Gebeleşme & & $163 b$ & $82 b$ & 46 & $542 \mathrm{a}$ & $309 a$ & $53 \mathrm{bc}$ & 233 & $256 \mathrm{a}$ & $816 b$ & $689 b$ \\
\hline Başaklanma & & $138 \mathrm{c}$ & $76 b$ & 43 & $541 \mathrm{a}$ & $316 a$ & $61 b$ & 225 & $255 \mathrm{a}$ & $790 \mathrm{~b}$ & $561 \mathrm{~b}$ \\
\hline Süt olum & & $127 \mathrm{c}$ & $79 b$ & 44 & $563 a$ & $316 a$ & $72 \mathrm{a}$ & 247 & $244 \mathrm{a}$ & $698 \mathrm{c}$ & $509 \mathrm{c}$ \\
\hline Hamur olum & & $114 \mathrm{e}$ & $78 \mathrm{~b}$ & 42 & $557 \mathrm{a}$ & $326 a$ & $78 \mathrm{a}$ & 231 & $248 \mathrm{a}$ & $711 \mathrm{c}$ & $522 \mathrm{c}$ \\
\hline & s.h. & 1.9 & 4.8 & 2.8 & 9.0 & 11.6 & 3.1 & 15.4 & 11.0 & 10.8 & 20.2 \\
\hline \multicolumn{12}{|l|}{ Unsur } \\
\hline Sap & & $89 b$ & $76 b$ & $24 b$ & $580 \mathrm{a}$ & $344 a$ & 64 & 236 & $280 \mathrm{a}$ & $702 b$ & $528 \mathrm{~b}$ \\
\hline \multirow[t]{2}{*}{ Yaprak } & & $218 \mathrm{a}$ & $96 a$ & $67 \mathrm{a}$ & $489 \mathrm{~b}$ & $264 b$ & 61 & 224 & $204 b$ & $868 \mathrm{a}$ & $747 \mathrm{a}$ \\
\hline & s.h. & 1.2 & 3.0 & 1.8 & 5.7 & 7.3 & 2.0 & 9.8 & 6.9 & 6.8 & 12.8 \\
\hline Gelişme Dönemi & Unsur & & & & & & & & & & \\
\hline Sapa kalkma & Sap & $186 \mathrm{~d}$ & 116 & $42 b$ & $493 d$ & 271 & 47 & 222 & 224 & $884 b$ & $779 a$ \\
\hline Sapa kalkma & Yaprak & $265 \mathrm{a}$ & 115 & $63 a$ & $448 \mathrm{e}$ & 241 & 49 & 207 & 192 & $930 \mathrm{a}$ & $852 a$ \\
\hline Gebeleşme & Sap & $95 \mathrm{e}$ & 77 & $22 c$ & $577 \mathrm{c}$ & 341 & 47 & 236 & 294 & $747 d$ & $591 b$ \\
\hline Gebeleşme & Yaprak & $231 b$ & 87 & $69 a$ & $506 \mathrm{~d}$ & 277 & 59 & 229 & 218 & $886 a b$ & $787 \mathrm{a}$ \\
\hline Başaklanma & Sap & $69 f$ & 65 & $20 \mathrm{c}$ & $585 \mathrm{bc}$ & 371 & 67 & 214 & 304 & $685 \mathrm{e}$ & $499 \mathrm{c}$ \\
\hline Başaklanma & Yaprak & $207 \mathrm{c}$ & 87 & $66 a$ & $496 \mathrm{~d}$ & 260 & 56 & 236 & 205 & $895 \mathrm{ab}$ & $803 a$ \\
\hline Süt olum & Sap & $55 \mathrm{~g}$ & 62 & $18 \mathrm{c}$ & $627 a$ & 356 & 76 & 271 & 280 & $594 f$ & $391 d$ \\
\hline Süt olum & Yaprak & $199 \mathrm{c}$ & 96 & $70 \mathrm{a}$ & $498 d$ & 275 & 68 & 223 & 207 & $803 c$ & $628 b$ \\
\hline Hamur olum & Sap & $41 \mathrm{~h}$ & 60 & $18 \mathrm{c}$ & $619 \mathrm{ab}$ & 383 & 84 & 236 & 300 & $598 \mathrm{f}$ & $382 d$ \\
\hline \multirow[t]{2}{*}{ Hamur olum } & Yaprak & $186 \mathrm{~d}$ & 96 & $66 \mathrm{a}$ & $494 d$ & 269 & 73 & 225 & 196 & $825 \mathrm{c}$ & $663 b$ \\
\hline & s.h. & 2.7 & 6.8 & 4.0 & 12.7 & 16.4 & 4.4 & 21.8 & 15.5 & 15.2 & 28.5 \\
\hline
\end{tabular}

${ }^{1}: \mathrm{HP}=$ Ham protein; HK=Ham kül; HY=Ham yağ; NDF=Nötr deterjan lif; ADF=Asit deterjan lif, ADL=Asit deterjan lignin; HS=hemiselüloz (NDF-ADF); SEL=(ADF-ADL); KMS=İn-vitro gerçek KM sindirilebilirliği; NDFS= In $n$-vitro NDF sindirilebilirliği; s.h.: standart hata

Çizelge 2. Başaklanma, süt olum ve hamur olum dönemlerinde başakların besin değeri (g/kg KM) ${ }^{1}$

\begin{tabular}{lllllllllll}
\hline Gelişme dönemi & HP & HK & HY & NDF & ADF & ADL & HS & SEL & KMS & NDFS \\
\hline Başaklanma & 113 & $36 \mathrm{~b}$ & 27 & $571 \mathrm{a}$ & $294 \mathrm{a}$ & $54 \mathrm{a}$ & 277 & $240 \mathrm{a}$ & $751 \mathrm{~b}$ & $598 \mathrm{a}$ \\
Süt olum & 127 & $45 \mathrm{a}$ & 28 & $543 \mathrm{a}$ & $287 \mathrm{a}$ & $55 \mathrm{a}$ & 256 & $231 \mathrm{a}$ & $687 \mathrm{c}$ & $462 \mathrm{~b}$ \\
Hamur olum & 119 & $38 \mathrm{~b}$ & 25 & $399 \mathrm{~b}$ & $174 \mathrm{~b}$ & $41 \mathrm{~b}$ & 225 & $133 \mathrm{~b}$ & $775 \mathrm{a}$ & $471 \mathrm{~b}$ \\
Standart hata & 9.3 & 1.2 & 2.2 & 17 & 5.2 & 2.2 & 18 & 3.0 & 4.1 & 14 \\
\hline
\end{tabular}

${ }^{1}: \mathrm{HP}=$ Ham protein; $\mathrm{HK}=$ Ham kül; $\mathrm{HY}=$ Ham yăg; $\mathrm{NDF}=$ Nötr deterjan lif; $\mathrm{ADF}=$ Asit deterjan lif, $\mathrm{ADL}=$ Asit deterjan lignin; $\mathrm{HS}=$ hemiselüloz (NDF-ADF); $\mathrm{SEL}=(\mathrm{ADF}-\mathrm{ADL}) ; \mathrm{KMS}=\dot{I}$-vitro gerçek KM sindirilebilirliği; $\mathrm{NDFS}=$ İn-vitro $\mathrm{NDF}$ sindirilebilirliği. 
Çizelge 3. Süt olum ve hamur olum dönemlerinde ölü dokuların besin değeri $(\mathrm{g} / \mathrm{kg} \mathrm{KM})^{1}$

\begin{tabular}{lllllllllll}
\hline Gelişme dönemi & HP & HK & HY & NDF & ADF & ADL & HS & SEL & KMS & NDFS \\
\hline Süt olum & 61 & 88 & 49 & 686 & 444 & 120 & 242 & 324 & 604 & 453 \\
Hamur olum & 71 & 83 & 55 & 673 & 442 & 120 & 230 & 322 & 597 & 432 \\
Standart hata & 3.7 & 1.6 & 6.4 & 15 & 21 & 2.5 & 18 & 24 & 5.2 & 9.9 \\
\hline
\end{tabular}

${ }^{1}: \mathrm{HP}=$ Ham protein; HK=Ham kül; HY=Ham yağ; NDF=Nötr deterjan lif; $\mathrm{ADF}=$ Asit deterjan lif, $\mathrm{ADL}=$ Asit deterjan lignin; $\mathrm{HS}=$ hemiselüloz $(\mathrm{NDF}-\mathrm{ADF}) ; \mathrm{SEL}=(\mathrm{ADF}-\mathrm{ADL}) ; \mathrm{KMS}=\dot{I}$-vitro gerçek KM sindirilebilirliği; $\mathrm{NDFS}=\dot{I}$ - -vitro $\mathrm{NDF}$ sindirilebilirliği.

HK içeriği kardeşlenme döneminde en yüksek $(\mathrm{P}<0.05)$ belirlenmiş, yapraklar saplardan ortalama olarak \%21 daha fazla $(\mathrm{P}<0.05)$ HK içermişlerdir. Başaklanma döneminden sonra sap ve yaprakların HK içerikleri değişmemiştir. Yaprakların HY içeriği ise bitkinin vejetasyon döneminden etkilenmezken $(\mathrm{P}>0.05)$, kardeşlenme döneminde sapların içerdiği HY içeriği, diğer dönemlerde saplarda belirlenen HY'dan daha fazla $(\mathrm{P}<0.05)$ belirlenmiştir. Yapraklar saplardan ortalama olarak \%63 daha fazla HY $(\mathrm{P}<0.05)$ içermişlerdir.

Yaprakların NDF içeriği sapa kalkma döneminde en düşük belirlenirken (448 g/kg; $\mathrm{P}<0.05)$, gebeleşmehamur olum dönemleri arasında değişmemiş $(\mathrm{P}>0.05)$. Buna karşın saplardaki NDF, süt olum dönemine kadar $\operatorname{artmış~}(\mathrm{P}<0.05)$, süt olum ve hamur olum dönemlerinde ise benzer $(\mathrm{P}>0.05)$ olmuştur. Saplar yapraklardan ortalama olarak \%16 daha fazla NDF $(\mathrm{P}<0.05)$ içermişlerdir. ADF ve SEL içeriği üzerine sadece gelişme dönemi ve morfolojik unsurun etkileri önemli $(\mathrm{P}<0.05)$ olarak belirlenmiş, sapa kalkma döneminde en düşük $(\mathrm{P}<0.05)$ belirlenen $\mathrm{ADF}$ ve selüloz düzeyi gebeleşme ve hamur olum dönemleri arasında değişmemiştir $(\mathrm{P}>0.05)$.

Yapraklar saplardan ortalama olarak \%23 daha fazla $(\mathrm{P}<0.05)$ ADF ve \%27 daha fazla $(\mathrm{P}<0.05)$ SEL içermişlerdir. Lignin düzeyi üzerine sadece gelişme döneminin etkisi önemli belirlenmiş, lignin miktarı süt olum dönemine kadar artmıştır $(\mathrm{P}<0.05)$. Yaprak ve sapların ortalama olarak içerdikleri lignin düzeyleri arasında bir farklılık belirlenmemiştir $(\mathrm{P}>0.05)$. Yaprak ve sapların HS düzeyleri bitki gelişimi ya da morfolojik unsurdan etkilenmemiştir.

Sindirilebilirlik değerleri (KMS ve NDFS) kardeşlenme döneminde en yüksek $(\mathrm{P}<0.05)$, süt olum ve hamur olum dönemlerinde en düşük $(\mathrm{P}<0.05)$ belirlenmiştir. Yaprakların KMS ve NDFS değerleri saplardan ortalama olarak sirasiyla, \%19 ve 29 daha yüksek belirlenmiştir. Yaprakların KMS ve NDFS değerindeki düşüş olgunlaşmaya bağlı olarak daha az ve geç $(\mathrm{P}<0.05)$ gerçekleşirken, sapların sindirilebilirlik değerlerindeki düşüş olgunlaşma ile daha belirgin ve daha fazla $(\mathrm{P}<0.05)$ olmuştur.

Tritikale başaklarının gebeleşme, süt olum ve hamur olum dönemlerinde belirlenmiş besin değerleri Çizelge 2'de verilmiştir. Gelişme döneminin başakların özellikle yapısal karbonhidrat içerikleri üzerine etkisi önemli bulunmuştur. Hamur olum döneminde başakların NDF, $\mathrm{ADF}$ ve $\mathrm{SEL}$ içeriği düşmüş $(\mathrm{P}<0.05), \mathrm{KMS}$ 'si se $\operatorname{artmıştır~}(\mathrm{P}<0.05)$.

Çizelge 3'de süt olum ve hamur olum dönemlerinde bitkide belirlenen ölü dokuların içermiş oldukları besin değerleri verilmiştir. Her iki dönemde de ölü dokuların besin maddesi içerikleri ile sindirilebilirlik değerleri arasında istatistiki anlamda bir farklılık tespit $(\mathrm{P}<0.05)$ edilmemiştir.

\section{Tartışma}

Yaprakların saplardan ve diğer morfolojik unsurlardan yüksek HP içerdiğine dair benzer sonuçlar Cherney ve Marten (1982) tarafindan arpa, buğday, tritikale ve yulaf için bildirilmiştir. Yaprak ve sapların HP içeriğindeki dikkat çekici bir konu, başaklanmanın ardından özellikle sapların içerdiği HP miktarındaki düşüş hızının yavaşlaması olmuştur. $\mathrm{Bu}$ durum başaklanmadan sonraki dönemlerde tüm bitkinin HP içeriğinin çok hızlı bir şekilde düşmeyeceğini göstermektedir (Khorasani ve ark., 1997; Nadeau, 2007; Filya, 2003).

Bitki gelişimine bağlı olarak tahıl hasıllarının hem yapraklarında hem de saplarında bitki hücre duvarını oluşturan karbonhidratları miktarının arttığı bildirilmiştir (Cherney ve Marten, 1982). Ancak mevcut çalışmada yaprakların NDF içeriği, gebeleşme-hamur olum dönemleri arasında; saplardaki NDF ise süt olum ve hamur olum dönemlerinde değişmemiştir. Yaprak ve sapların HS düzeyleri bitki gelişimi ya da morfolojik unsurdan etkilenmemesi, gebeleşme döneminden sonra sapların içerdiği NDF düzeyindeki artışın HS ya da SEL miktarından ziyade lignin içeriğinin artmasından kaynaklandığını göstermektedir.

Gebeleşme döneminden süt olumuna kadar ligninin yapraklardan ziyade sap kısımlarında artma eğilimi göstermesi $(\mathrm{P}=0.07)$ sapların NDFS değerindeki hızlı 
düşüşe bir neden olarak gösterilebilir. Nitekim NDFS, kardeşlenme dönemi ile hamur olum dönemi arasında yapraklarda $852 \mathrm{~g} / \mathrm{kg}$ 'dan $663 \mathrm{~g} / \mathrm{kg}$ 'a $\% 22$ düşerken, saplarda $779 \mathrm{~g} / \mathrm{kg}$ 'dan $382 \mathrm{~g} / \mathrm{kg}$ 'a kadar \%51 düşmüştür. Saplardaki NDFS değerindeki hızlı düşüşe diğer bir nedende ligninle polisakkaritler arasındaki çapraz bağlar sonucunda oluşan lignin polimerlerinin bitkinin olgunlaşmasına bağlı olarak artması gösterilebilir (Jung, 2012). Bu durum ayrıca saplarda bitki polisakkaritleri ile lignin arasındaki çapraz bağların yapraklara kıyasla daha yoğun şekillendiğine de işaret etmektedir.

Araştırma sonuçlarında dikkat çekici diğer bir konu sapa kalkma döneminde sap ve yapraklarının ortalama olarak 907 g/kg KMS değerine sahip olmalarıdır. Tahıl hasıllarının erken vejetatif gelişme dönemindeki böylesine yüksek sindirilebilirlik değerleri Coblentz ve Walgenbach (2010) tarafindan yulaf, tritikale ve buğday hasılları için de bildirilmiştir (891-912 g/kg). Tritikale saplarının erken vejetatif dönemde sahip oldukları yüksek KMS ve NDFS değerleri ile içermiş oldukları yüksek HP (226 g/kg KM) bu dönemlerde yapılacak bir otlatmanın yüksek verimli ruminantların yüksek verimini destekleyeceğini ve yoğun yemlerden önemli ölçüde tasarruf ettireceğini göstermektedir. Hasılların erken dönemde otlatılmalarının hemen ardından yeniden büyüyebilmeleri (Keles ve ark., 2013) konunun önemini daha da artırmaktadır. Bu durum ayrıca tahıl hasıllarının erken dönemlerde kaba yem kaynağı olarak kullanılmalarının ardından yeniden büyüme potansiyellerinin ortaya konulması ve Ülkemizin farklı coğrafi bölgelerine uygun çeşitlerin geliştirilmesine yönelik çalışmaların yapılması gerekliliğini ortaya koymaktadır. Hamur olum döneminde dane oluşumuna bağlı olarak bitki hücre duvarını oluşturan karbonhidratlardaki düşüş ve bunun sonucunda artan KMS diğer araştırıcılar (Cherney ve Marten, 1982; Khorasani ve ark., 1997; Nadeau, 2007) tarafindan da bildirilmiştir. Buna karşın başakların içerdiği hücre duvarı unsurlarının sindirilebilirliği de düşmüştür. $\mathrm{Bu}$ durum saplardaki NDFS değerinin düşüşüne benzer şekilde bitki olgunlaşması ile ligninle hücre duvarı karbonhidratları arasındaki çapraz bağların başaklarda da arttığını göstermektedir.

Ölü dokuların besin değeri NRC (2001) tarafindan buğday samanı için verilen ortalama değerlerin üzerinde belirlenmiştir. Ölü dokular özellikle erken ya da geç gelişme döneminde kuruyan yapraklardan oluşmaktadır. $\mathrm{Bu}$ nedenle yaprak oranı fazla olan tahıl türü ya da çeşitlerinin dane hasadından sonra kalan kısımları içerisin de yaprak oranı da daha fazla olacağından üretilecek samanın besin değerinin artacağını göstermektedir. Nitekim bu nedenle Feyissa ve ark. (2008) tanelik çeşitlerin ıslahında yaprak oranı fazla olan çeşitlerin seçiminin üretilecek samanın besin değeri açısından önemli olduğu bildirmişlerdir.

Sonuç olarak ruminantların beslenmeleri açısından kaba yemlerin içermiş oldukları besin maddeleri ve bunların sindirilebilirlik değerlerinin beraber ele alınması gerekmektedir. $\mathrm{Bu}$ açıdan, tritikale hasılında yapraklar en yüksek besin değerine sahip unsur olarak belirlenmiştir. Ayrıca bitki olgunlaşmasına bağlı olarak yaprakların besin değerindeki düşüş saplardan daha düşük olmuştur. Farklı morfolojik unsurların özellikle sindirilebilirlik değerindeki düşüş oranı başaklanmadan sonra daha belirgin olmuş, hamur olum döneminde bitkide nişasta birikimine bağlı olarak yeniden artmıştır. $\mathrm{Bu}$ nedenle başaklanmanın gerçekleşmesi durumunda kaba yem amaciyla yapılacak bir hasadın hamur olum döneminde yapılmasının gerektiği sonucuna varılmıştır.

\section{Kaynaklar}

Albayrak, S., Zeki, M., Töngel, Ö. 2006. Tritikale (X Triticosecale Wittmack) hatlarında kuru ot ve tohum verimi ile bazı tarımsal özellikler. S.D.Ü. Ziraat Fakültesi Dergisi 1(1):13-21.

Helsel, Z.R., Thomas, J.W. 1987 Small grains for forage. J. Dairy Sci. 70: 2330-2338.

Khorasani, G.R., Jedel, P.E., Helm, J.H., Kennelly, J.J. 1997.Influence of stage of maturity on yield components and chemical composition of cereal grain silages. Can. J. Anim. Sci. 77: 259-267.

Coblentz, W.K., Walgenbach, R.P. 2010. Fall growth, nutritive value, and estimation of total digestible nutrients for cereal-grain in the North-Central United States. J. Anim. Sci. 88: 383-399.

Nadeau, E. 2007. Effects of plant species, stage of maturity and additive on the feeding value of wholecrop cereal silage. J. Sci. Food Agr. 87(5): 789-801.

Rustas, B.O., Bertilsson, J., Martinsson, K., Elverstedt, T., Nadeau, E. 2011. Intake and digestion of wholecrop barley and wheat silages by dairy heifers. J. Anim. Sci. 89: 4131-4141.

Emile, J.C., Jobim, C.C., Surault, F., Barriere, Y. 2007. Genetic variations in the digestibility in sheep of selected whole-crop cereals used as silages. Animal 1(8): 1122-1125.

McCartney, D.H, Vaage A.S. 1994. Comparative yield and feeding value of barley, oat and triticale silages. Can J. Anim. Sci. 74: 91-96.

Cherney, J.H., Marten, G.C. 1982. Small grain crop potential: II. Interrelationships amoung biological, chemical, Morphological, and anatomical 
determinants of quality. Crop Sci. 22: 240-245.

A.O.A.C. 2003. Official Methods of Analysis of AOAC International. $17^{\text {th }}$ ed., $2^{\text {nd }}$ Rev., Gaithersburg, MD, USA, Association of Analytical Communities.

Van Soest, P.J, Robertson, J.B., Lewis, B.A. 1991. Method for dietary fiber, neutral Detergent fiber, and non-starch polysaccharides in relation to animal nutrition. J. Dairy Sci. 74: 3583-3597.

SPSS, 2010. SPSS for Windows, Version 17., SPSS Inc. Chicago.

Filya, I. 2003. Nutritive value of whole crop wheat silage harvested at three stages of maturity. Anim. Feed. Sci. Tech. 103: 85-95.
Jung, H.J.G, Samac, D.A, Sarath, G. 2012. Modifying crops to increase cell wall digestibility. Plant Sci. 185-186: 65-67.

Keles, G., Ates S., Coskun., B, Isık, S. 2013. Re-growth yield and nutritive value of winter cereals. In, Proceedings 22th International Grassland Congress 15-19 September, Sydney, Australia, pp. 951-952.

NRC 2001. Nutrient requirements of dairy cattle. $7^{\text {th }}$ ed., National Academy Press, Washington, DC, USA.

Feyissa, F., Tolera, A., Melaku, S. 2008. Proportions of morphological fractions of oats (Avena sativa L.) as affected by variety and growth stage. Livest. Res. Rural Dev. 20 (6): 1-17. 